\title{
Location Suitability of Ado-Awaye Suspended Lake, Oyo State, Nigeria for Mountain Tourism. A Geospatial Technology Approach
}

\author{
Oluwatobi E. OLANIYI ${ }^{*}$, Busola G. BADA ${ }^{1}$ \\ ${ }^{*}$ Corresponding author \\ ${ }^{1}$ Federal University of Technology, Department of Ecotourism and Wildlife Management, Akure, NIGERIA \\ E-mail: oeolaniyi@futa.edu.ng \\ DOI: 10.24193/JSSPSI.2020.6.06 \\ https://doi.org/10.24193/JSSPSI.2020.6.06
}

K e y w o r d s: mountain tourism, analytic hierarchy process, Ado-Awaye Suspended Lake, Nigeria, analytical location finding, tourism planning

\begin{abstract}
A B S T RACT
The study aimed to determine the location suitability of Ado-Awaye Suspended Lake (ASL) and its environs, Nigeria for mountain tourism using a geospatial technology approach as well as the analytic hierarchy process (AHP) to calculate the criteria evaluation weights. Secondary data collection and on-field observation methods were employed to collect the a spatial and spatial information on ecotourism attractions and support facilities of ASL. This paper employed five criteria (diversity, fragility, aesthetic, difficult access, niche) and seven factors to evaluate the suitable location for mountain tourism activities and development. A total of fourteen ecotourism attractions and support facilities were identified with predominant tourism and spiritual activities. The AHP results showed that the slope and terrain ruggedness had the maximum weights (27.87\%), while the maximum rainfall had the minimum weights (4.05\%). The largest portion (117.05 hectares, 61.40\%) of ASL, associated with the front country zone, was found suitable for tourism activities and development. On the other hand, the smallest portion ( 0.18 hectares, $0.10 \%$ ) was found suitable for tourism activities and development associated with the backcountry zone. However, ASL is rich in ecotourism attractions but with inadequate and poorly maintained support facilities to enhance the experience and satisfaction of mountain tourists. It is highly suitable for nature-oriented activities such as camping, hiking, native/ethnic culture, wildlife viewing and nature photography. Therefore, relevant authorities and other major stakeholders should adopt the location suitability models for the planning and development of mountain tourism in ASL.
\end{abstract}

\section{INTRODUCTION}

Globally, mountain regions harbour many tourism attractions, while mountain tourism activities represent $15-20 \%$ of the tourism industry (Silva et al., 2014). This attribute makes them some of the most attractive tourism destinations globally with an annual influx of 500 million tourists (Thomas et al., 2006; Panov et al., 2013). Despite global efforts towards mountain tourism development, many countries are yet to harness the potential of this sub-sector. In recent years, mountain issues have been a focus in the policy framework of many national and international agencies and governments, although with slow and increasing global awareness (Godde et al., 2000; United Nations General Assembly, 2016).

Mountain tourism has been one of the activities earmarked and pivotal within the policy framework to open high potential yet less visited mountain areas (GOK, 2006; World Tourism Organization, 2018). However, a wide gap still exists between the role of mountain tourism into the overall 
development of mountain regions and the improvement of communities' living standards within these regions.

The gap can be attributed to the poor destination image of most mountain regions in the world, especially in developing countries with lack of political will towards mountain tourism planning and development. According to Kozak et al. (2003) and Nepal and Chipeniuk (2005), destination image is closely linked to the attractiveness and competitiveness of a mountain tourism destination. However, its management coupled with poor destination packaging have been observed to be some of the most important challenges of tourism marketing (Kian and Zadeh, 2014; Olaniyi et al., 2015; Răcăşan, 2015). No matter the richness of a mountain region in tourist attractions, destination packaging and image management remains a key to harness mountain tourism potential. In light of this, Nigeria is one of the countries with significant and diverse natural, geographical, historical and cultural heritage assets such as Ado-Awaye Suspended Lake (ASL) within mountain regions, yet untapped.

ASL is one of the two hanging lakes in Africa and in the world. It has vast potential for the development of a sustainable tourism sector in Nigeria and, implicitly, Africa largely due to its competitive advantage. However, the potential mountain tourism destination is not without problems, namely the lack of basic cognizance of the economic importance of tourism as an industry. Besides, poor awareness of its positive impact as a potential source of foreign exchange and employment, inadequate mountain tourism experts and weak promotional activity could be issues that militate against its planning and development. Dabour (2003) opined that some basic infrastructures (hotels and lodging services, transportation and communication, safety and security and tourism information services) are necessary to provide the standards of facilities and services required to attract tourists to a destination. These basic requirements entail appropriate planning to integrate mountain ecosystem and biodiversity values into the national and local development processes.

Until now, no study has been yet carried out to employ the capability of remote sensing and geographic information technology to map the potential zones for mountain tourism activities within a mountain region in Nigeria. Therefore, this study aimed to determine the current status and suitable locations for tourism activities and development of mountain tourism in the area of ASL, Oyo State, Nigeria.

\section{THEORY AND METHODOLOGY}

\subsection{Literature review}

Mountains cover $24 \%$ of the Earth's surface and accommodate $12 \%$ of the global population (Huddleston et al., 2003; Richins et al., 2016). Over the 52 years, the region that contains unique attractions has drawn interest to mountain research for tourism purposes. Until very recently, tourism researches focused on mountain areas from physical, ecological and environmental perspectives (Smethurst, 2000; United Nations University, 2004). However, attention has shifted to the mountain tourism product, which consists of a system of attractions and support facilities providing goods and services to maximize the satisfaction of tourists (Kruk et al., 2007). This required integrated approaches to ensure appropriate planning and sustainable development towards tourism destination zoning in mountain regions and minimal ecological footprints during tourists' visits. The prospective of a tourism destination to attract tourists is dependent on the spatial distribution of attractions and support facilities (Ding et al., 2011; Blasco et al., 2013; Siakwak, 2018).

Over the years, geographic information system has been employed by researchers for tourism destination zoning of mountain regions (Zyryanov and Korolev, 2009; Blasco et al., 2013). Nevertheless, Nepal and Chipeniuk (2005) suggested a more comprehensive and robust conceptual framework for an appropriate zoning of mountain destinations. These authors highlighted six mountain resource characteristics (diversity, marginality, difficult access, fragility, niche and aesthetics) essential to identify zones for mountain tourism. The quantification and integration of the mountain resource characteristics produce a distinct pattern of three mountain recreational zones (tourism centre, frontcountry and backcountry). Furthermore, Nepal and Chipeniuk (2005) recommended a spectrum of activities to be carried out in the mountain recreational zones. Based on this conceptual framework, this study employed the analytic hierarchy process and geographic information systems to determine the most suitable locations for the activities and development of mountain tourism in the case of ASL, Oyo State, Nigeria.

\subsection{Geographical description}

ASL lies about $20 \mathrm{~km}$ West of Iseyin, Iseyin Local Government Area of Oyo State (Fig. 1).

The lake is located in the Iyake Mountains that sprawl around the sleepy town with a land cover area of 190.62 hectares. It falls within Latitudes $07^{\circ} \mathrm{O} 48^{\prime} \mathrm{Oo}$ "N and $07^{\circ} \mathrm{O} 54^{\prime} \mathrm{Oo}$ "N $\mathrm{N}$ and Longitudes $003^{\circ} \mathrm{O} 18^{\prime} \mathrm{Ooo}$ "E and o03 O30'00"E (Ibrahim, 2015). The area is mainly characterized by rocks with a dynamic structure and impeccable display such as the Ishage rock, which can be a resource for tourism attraction. There is no major river within the catchment. A stair of 369 steps leads through vegetation consisting of grassy savanna with scattered shrubs and open secondary forests to the plains on the mountain top. 

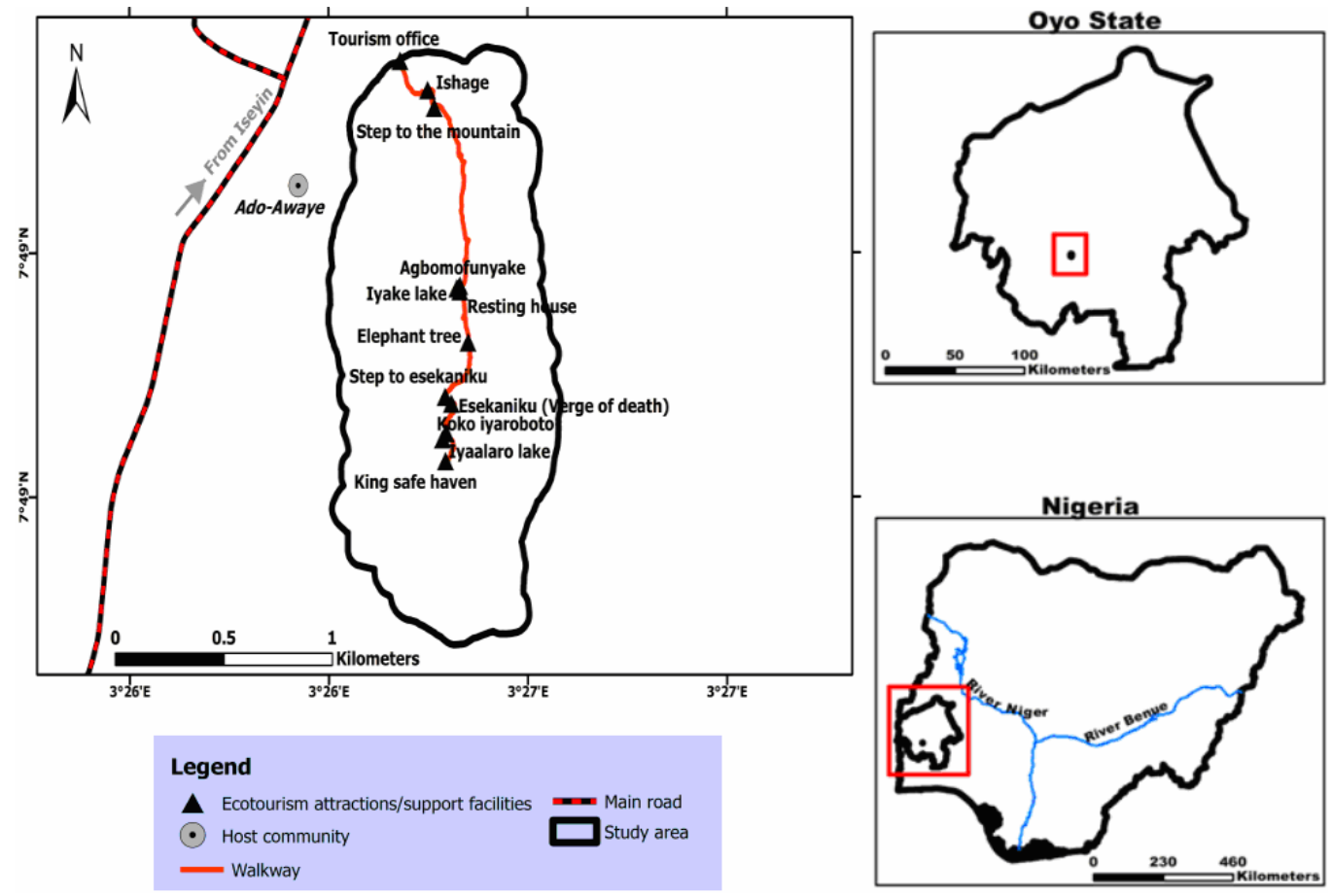

Fig. 1. Ado-Awaye Suspended Lake, Oyo State, Nigeria.

The study area has an elevation of $433 \mathrm{~m}$ above the sea level with a maximum annual rainfall of $1790-1850 \mathrm{~mm}$. It is characterized by an equatorial climate with dry and wet seasons and relatively high humidity. The dry season lasts from November to March while the wet season starts in April and ends in October. The average daily temperature ranges between 20 and $35^{\circ} \mathrm{C}$ almost throughout the entire year.

\subsection{Data sources}

During the modelling process, the sources of data collected were as follows: land use/land cover and Normalized Difference Vegetation Index, NDVI maps at $30 \mathrm{~m}$ spatial resolution (Landsat 8 OLI/TIRS satellite imageries - January 2019, provided by the United States Geological Services); SRTM DEM at $30 \mathrm{~m}$ spatial resolution (provided by the United States Geological Services) used for the extraction of the slope, terrain ruggedness index and elevation; culturally-related ecotourism attractions proximity (field survey on April 2019); maximum rainfall at 2.5 arc-minute resolution (WorldClim); study area boundary (field survey on April 2019).

\subsection{Methods}

The multi-criteria decision method (MCDM) using AHP and GIS were used to develop the location suitability model for mountain tourism in the study area using the framework in Figure 2.

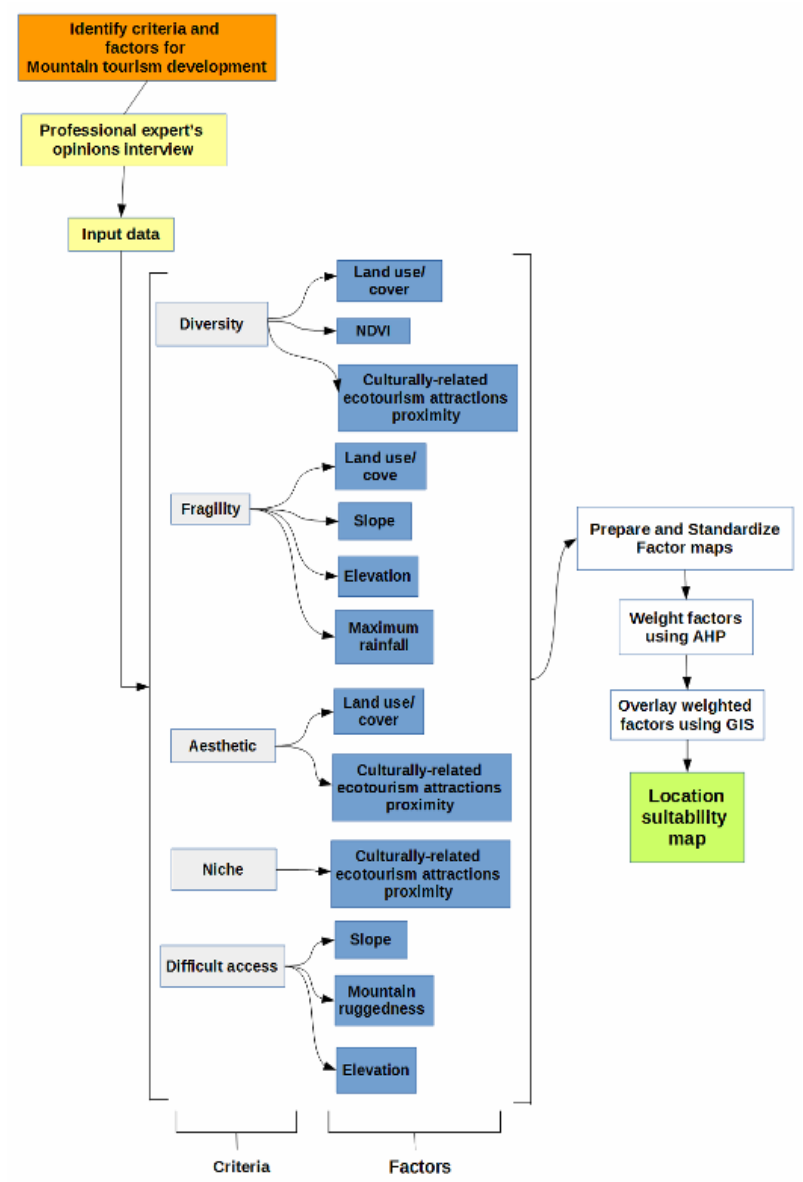

Fig. 2. Framework of location suitability for mountain tourism development in the area of Ado-Awaye Suspended Lake, Oyo State, Nigeria. 
The Landsat satellite imageries acquired in January 2019 for ASL and its environment were used to derive the land use/land cover and NDVI. Supervised classification using maximum likelihood classification algorithm was employed to categorize images and to extract three land use/land cover classes for ASL (rock outcrops/built-up areas/bare grounds, grassy savanna with scattered shrubs, open secondary forests). The modification of the United States Geological Survey Land Classification Scheme (Anderson et al., 1976) was made according to the present land use/land cover scenario. Error matrices and kappa statistics were computed using Quantum Geographic Information System software (QGIS version 3.8.1). The overall accuracy (kappa statistics) of ASL was of $89.00 \%$ (0.8537). Secondary data collection method was employed to collect non-spatial information on ecotourism attractions and support facilities from the management authority of the study area, while spatial data were collected through on-field observation with the help of a hand-held Global Positioning System device (GARMIN 78S). During the study, a detailed field survey was performed in the area to identify natural and cultural assets.

The identification of suitable locations for tourism activities and development is based on six criteria and seven factors (Table 1) namely: land use land cover, NDVI (Normalized Differential Vegetation Index), culturally-related ecotourism attractions (m), slope (degrees), mountain ruggedness, elevation (m), maximum rainfall (mm). Therefore, ecotourism experts' response through the analytic hierarchy process (AHP) and geographic information system were employed to calculate the criteria evaluation weights.

Table 1. Factors and criteria for location suitability of tourism activities and development in the area of Ado-Awaye Suspended Lake, Oyo state, Nigeria.

\begin{tabular}{|c|c|c|c|c|c|}
\hline \multirow{2}{*}{ Factors } & \multirow{2}{*}{ Criteria } & \multicolumn{3}{|c|}{ Suitability classes } & \multirow{2}{*}{ References (for criteria) } \\
\hline & & Centre zone & Frontcountry & Backcountry & \\
\hline Land use/Land cover & $\begin{array}{l}\text { Diversity, Fragility, } \\
\text { Aesthetic }\end{array}$ & $\begin{array}{l}\text { Rock Outcrops/Built- } \\
\text { up areas/Bare } \\
\text { grounds }\end{array}$ & $\begin{array}{l}\text { Grassy with } \\
\text { scattered shrubs } \\
\text { savanna }\end{array}$ & $\begin{array}{l}\text { Open } \\
\text { Secondary } \\
\text { Forests }\end{array}$ & $\begin{array}{l}\text { Price and Neville(2003) } \\
\text { Nepal and Chipeniuk } \\
\text { (2005) }\end{array}$ \\
\hline NDVI & Diversity & $0.059-0.150$ & $0.151-0.200$ & $>0.200$ & Price and Neville (2003) \\
\hline $\begin{array}{l}\text { Culturally-related } \\
\text { ecotourism attractions (m) }\end{array}$ & Diversity & $>480$ & $241-480$ & $0-240$ & Stepp (2000) \\
\hline Slope (Degrees) & $\begin{array}{l}\text { Difficult access, } \\
\text { Fragility }\end{array}$ & $0-5$ & $6-15$ & $>15$ & $\begin{array}{l}\text { Nepal and Chipeniuk } \\
(2005)\end{array}$ \\
\hline Mountain ruggedness & Difficult access & $0-80$ & $81-116$ & $>116$ & $\begin{array}{l}\text { Riley et al. (1999), Nepal } \\
\text { and Chipeniuk (2005) }\end{array}$ \\
\hline Elevation (m) & $\begin{array}{l}\text { Difficult access, } \\
\text { Fragility }\end{array}$ & $190-250$ & $251-350$ & $>350$ & $\begin{array}{l}\text { Nepal and Chipeniuk } \\
(2005)\end{array}$ \\
\hline Maximum rainfall (mm) & Fragility & $179.0-181.0$ & $181.1-183.0$ & $>183.0$ & $\begin{array}{l}\text { Nepal and Chipeniuk } \\
(2005)\end{array}$ \\
\hline $\begin{array}{l}\text { Ecotourism attractions and } \\
\text { support facilities }(\mathrm{m})\end{array}$ & Niche, Aesthetic & $>480$ & $241-480$ & $0-240$ & $\begin{array}{l}\text { McCool and Lachapelle, } \\
\text { (2000), Nepal and } \\
\text { Chipeniuk (2005) }\end{array}$ \\
\hline
\end{tabular}

A semi-structured expert's opinion interview with two sections of questions was constructed and used in the collection of data. Section A included items related to demographic characteristics of respondents, while Section B consisted of one item on the factors determining the choice of location suitability for mountain tourism activities and development. The item in Section B was designed using the five-point Likert scale, that is, Highly Important, Important, No Idea, Not Important and Highly Not Important. Experts were selected and interviewed according to their knowledge on location suitability for mountain tourism activities and development coupled with their experience in tourism, ecology, wildlife conservation, economic and natural resource management. Twelve tourism/biodiversity professionals and management staff from the Federal University of Technology Akure (Department of Ecotourism and Wildlife Management) were consulted for the interview.
AHP also provided measures to mathematically determine the inconsistency of judgments to ensure credibility of the relative significance used. Based on the properties of reciprocal matrices, the consistency ratio index (CR) can be calculated as shown in equation 1. Saaty (1980) suggested that if CR is smaller than 0.10, the degree of consistency is fairly acceptable. But if it is larger than 0.10, then there are inconsistencies in the evaluation process, and the AHP method may not yield meaningful results. More details of the CR calculation were given in Chu and Liu (2002):

$$
C R=\frac{C I}{R I}
$$

where:

CR - Consistency Ratio;
CI - Consistency Index;
RI - Relative Index. 
However, each factor was categorized and their suitability scores were presented in the standardized format as shown in Table 1. That is, three suitability classes (tourist centre, front country, backcountry) and 1 (tourist centre) to 3 (backcountry), respectively. Thus, the total suitability score from each factor was computed to develop the location suitability model for mountain tourism in the study area. The mountain tourism continuum framework developed by Nepal and Chipeniuk (2005) was employed to categorize landscape based on Jenks Natural Break Classification into the three suitability classes (tourist centre, front country, backcountry) for mountain tourism activities and development.

\section{RESULTS AND DISCUSSION}

\subsection{Ecotourism attractions and support facilities in the study area}

Table 2 presents the spatial and aspatial attributes of ecotourism attractions and support facilities in ASL and environs, Oyo State, Nigeria. A total of fourteen (14) ecotourism attractions and support facilities were identified: seven ecotourism attractions (Ishage, Iyake Lake, Agbomofunyake, Elephant tree, Esekaniku, Iya Alaro Lake and King Safe Haven) and seven ecotourism attraction and support facilities. The ecotourism attractions and support facilities were found to be located between $434 \mathrm{~m}$ (the highest altitude) and $125 \mathrm{~m}$ (the lowest attitude). The ecotourism attractions and support facilities were both natural and man-made. Most of the ecotourism attractions have been available for over 1000 years, whilst the support facilities were constructed in $1999 / 2000$, of which the most recent was constructed in $2017 / 2018$.

This study revealed that ecotourism attractions and support facilities in the study area could make this destination more important and attractive for tourism development on national and global scales although, a few of them (tourism office and the steps to the mountain) are in poor conditions. The dilapidated condition of these facilities can be attributed to their low maintenance. According to Olaniyi and Atalor (2018), there is a strong relationship between tourism development and the maintenance of tourism infrastructures. That is, tourism infrastructure forms the basis of tourism development coupled with the sustainable resource utilization in ecotourism destination (Olaniyi and Atalor, 2018). Ecotourism attractions and support facilities in the Ado-Awaye area are the items that made the destination core tourism centre (Formica, 2002).

Support facilities are mainly built from the following construction materials: cement, sand, stone, bricks, iron sheet, wood, nails, water and clay. The event hall at one of the hotels has the highest carrying capacity (500), while the King safe haven has the least carrying capacity (1). Generally, most ecotourism attractions and support facilities experience the high intensity of patronage except for the tourism office, resting house, Koko Iyaroboto, the king safe haven and Hotel de infinity. Based on these ecotourism attractions and support facilities, the predominant activities developed are tourism and spiritual activities. Most of the ecotourism attractions and support facilities are in good condition, while one (Resting house) and two others (Koko Iyaroboto and steps to the mountain) are dilapidated and under-construction, respectively.

The intensity of patronage of ecotourism attractions and support facilities at the destination is low due to some issues in the community (combat among the community's citizens who to be the king) and lack of management, for example, the king safe haven and the Koko Iyaroboto experience low intensity of investment because there has been no king in the community for 33 years. Hotels around the destination have a low intensity of usage and investment because of poor publicity, location, deplorable road network, inadequate protection of lives and property. This assertion is in line with the findings of Nadube and Akahome (2017) who revealed the following challenges that have been faced in the southern region of Nigeria poor facility aesthetics of the destination, poor consumer purchasing power, political instability and violence, high rate of crime against humanity, unsafe airspace, inefficient telecommunication and internet services, poor facility aesthetics of the destination, national insecurity, multiplicity of fines and taxes, and high operational costs (Nadube and Akahome, 2017).

The predominant activities within this mountain area are tourism and spiritual activities. In Mount Kilimanjaro, trekking is the key tourism activity performed by adventure tourists who aim to reach the summit. There have been no other means of publicity of the ecotourism attractions and support facilities except for the usage of handbills at the Hotel de infinity. In addition, inappropriate distribution of amenities, coupled with the low level of advertisement (triggering less general awareness about attractions and potential of tourism), makes the problem even more complicated. This is consistent with the empirical findings of Jeroen (2017) who opined that awareness should be created to improve an ecotourism destination image.

\subsection{Factors that determine location suitability for mountain tourism}

The criteria importance judgment matrix and weights of mountain tourism suitability in the study area is shown in Table 3. 
Table 3. Evaluation criteria importance judgment matrix and weights of mountain tourism suitability in the area of AdoAwaye Suspended Lake, Oyo State, Nigeria.

\begin{tabular}{l|rrrrrrrrr} 
Factors & \multicolumn{1}{|c}{ C1 } & \multicolumn{1}{c}{ C2 } & \multicolumn{1}{c}{ C3 } & C4 & C5 & C6 & C7 & $\begin{array}{c}\text { Weight } \\
\text { (\%) }\end{array}$ & $\begin{array}{c}\text { Rank } \\
\text { NDVI (C1) }\end{array}$ \\
Proximity to culturally-related & 1 & 1.00 & 1.00 & 3.00 & 1.00 & 7.00 & 3.00 & 10.05 & 3 \\
ecotourism attractions (C2) & 1.00 & 1 & 1.00 & 3.00 & 1.00 & 7.00 & 3.00 & 10.05 & 3 \\
Slope (C3) & 1.00 & 1.00 & 1 & 3.00 & 1.00 & 7.00 & 3.00 & 27.87 & 1 \\
Terrain Ruggedness Index (C4) & 0.33 & 0.33 & 0.33 & 1 & 0.33 & 5.00 & 1.00 & 27.87 & 1 \\
Elevation (C5) & 1.00 & 1.00 & 1.00 & 3.00 & 1 & 7.00 & 3.00 & 10.05 & 3 \\
Maximum rainfall (C6) & 0.14 & 0.14 & 0.14 & 0.20 & 0.14 & 1 & 5.00 & 4.05 & 7 \\
Land use/land cover classes (C7) & 0.33 & 0.33 & 0.33 & 1.00 & 0.33 & 0.20 & 1 & 10.05 & 3
\end{tabular}

Consistency ratio $(\mathrm{CR})=0.007$, Consistency Index $(\mathrm{CI})=0.03$, Lambda, $\lambda=7.057$, Relative Index $(\mathrm{RI})=4.29$

Based on the AHP results, slope and terrain ruggedness had the maximum weights whilst rainfall had minimum weights (4.05\%), with consistency ratio, Consistency Index (CI), Lambda $(\lambda)$ and Relative Index (RI) of 0.007 , 0.03 , 7.057 and 4.29 respectively. This research revealed that the calculated consistency ratio (CR) from pairwise comparison matrix is 0.007 (less than 0.10), which indicates that a reasonable level of consistency in the pairwise comparisons and weights is acceptable. The AHP method was applied to determine the relative importance of all selected factors. Analytic Hierarchy Process (AHP) is one of multi-criteria decision-making methods that was originally developed by Saaty (1980). The AHP result revealed that slope and Terrain Ruggedness Index are important criteria and have great influence on the location suitability for tourism activities and development in the area of ASL. This research revealed that the calculated consistency ratio (CR) from pairwise comparison matrix is 0.007 (less than 0.10), which indicates that a reasonable level of consistency in the pairwise comparisons and weights is acceptable.

Figures $3 \mathrm{a} ., 3 \mathrm{~b}$ and Table 4 show the pictorial representation and attributes of factors for location suitability for mountain tourism activities and development in the study area.
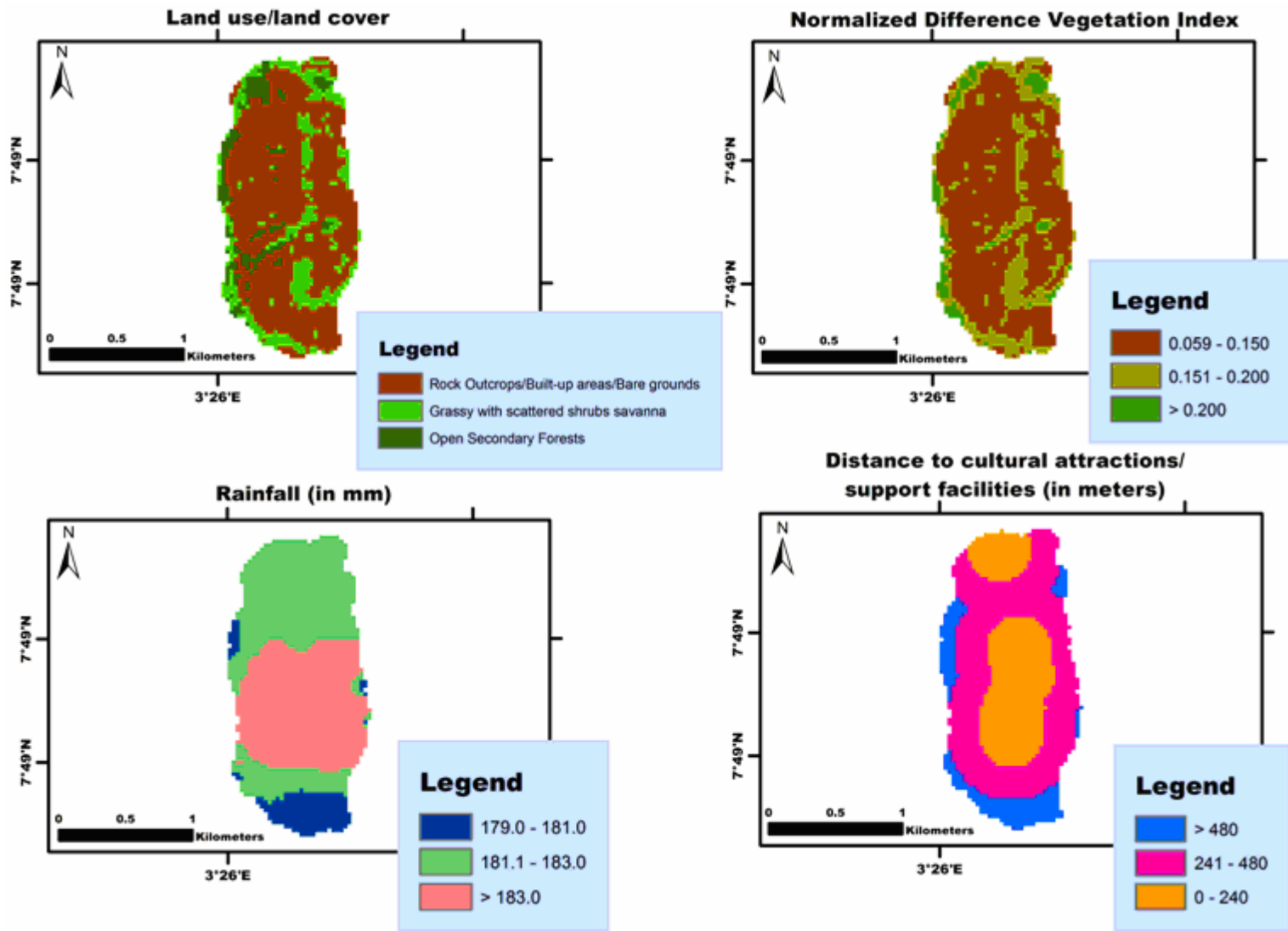

Fig. 3a. Pictorial representation of the factors for location suitability for mountain tourism activities and development in the area of Ado-Awaye Suspended Lake, Oyo State, Nigeria. 

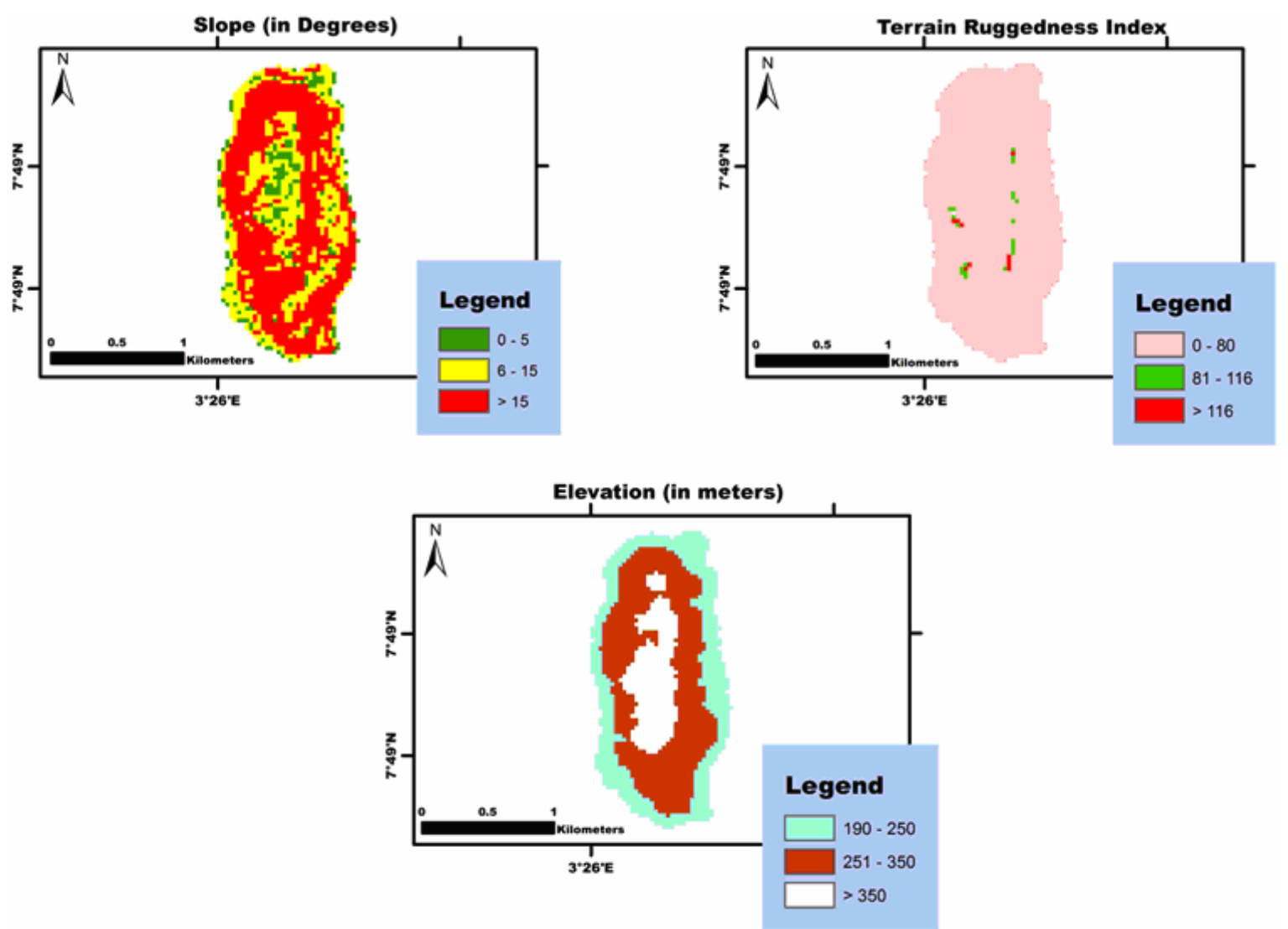

Fig. 3b. Pictorial representation of the factors for location suitability for mountain tourism activities and development in the area of Ado-Awaye Suspended Lake, Oyo State, Nigeria.

Table 4. Attributes of the factors for location suitability of mountain tourism activities and development in the area of AdoAwaye Suspended Lake, Oyo State, Nigeria.

\begin{tabular}{l|r}
\multicolumn{1}{c|}{ Factors } & \multicolumn{1}{c}{ Range of values } \\
\hline Normalized Difference Vegetation Index (NDVI) & $0.059-0.282$ \\
Culturally-related ecotourism attractions (m) & $0-724.52$ \\
Slope (Degrees) & $0.00-71.33$ \\
Terrain Ruggedness Index (m) & $0.00-172.45$ \\
Elevation (m) & $190-433$ \\
Maximum rainfall (m) & $179-185$ \\
Land use/land cover (LULC) classes, 2019 & $133.92(70.25)$ \\
- Rock outcrops/Built-up areas/Bare grounds & $17.01(8.92)$ \\
- Open Secondary Forests & $39.69(20.82)$ \\
\hline
\end{tabular}

Total area $=190.62$ ha, , LULC cells in Area(ha) (share - \%). Source: Fick and Hijmans (2017), Field survey (2019).

Results showed that the NDVI values ranged from 0.059 - 0.282, the distance to the cultural attractions/support facilities ranged from o to 724.52 $\mathrm{m}$, slope ranged between 0.00 and 71.33 degrees, mountain ruggedness ranged from 0.00 to 172.45 , elevation ranged from $190 \mathrm{~m}$ to $433 \mathrm{~m}$ and the maximum rainfall ranged between $179 \mathrm{~mm}$ and 185 $\mathrm{mm}$. However, the Rock Outcrops/Built-up areas/Bare grounds covered the highest landmass of 133.92 hectares (70.25\%), while the open secondary forest covered the least of the land, of 17.01 hectares (8.92\%).

Land cover had been described as the observed biophysical cover of the earth's surface, a synthesis of many processes taking place on the land and one of the most easily detectable indicators of human intervention on land (Gregorio et al., 2016). It is an important criterion, of great influence on land suitability for mountain tourism. This is consistent with the findings 
of Bunruamkaew and Murayama (2012) and Wu et al. (2015) who stated that land use/land cover of a Nature Reserve in China and Surat Thani province in Thailand contributed to their suitability for ecotourism development. Intensive human activities in ecologically sensitive areas, such as tourism, can create various irreversible change and trigger negative impacts on the surrounding environment and existing ecological processes, due to the degradation of natural resources, vegetation structure and alterations in the size of the habitat patch, increased deforestation (Tourism Queenland, 2002; Olaniyi, 2017).

The study revealed that the slope of the terrain surface can be expressed in degrees. Much of the tourism centres have flat topography. Slopes are important for mountain tourism because all-terrain features are derived from complex landmasses. As indicated in the research conducted by Tewodros (2010), elevation is one of the most important dimensions of attractiveness in an area, and higher elevation range has a higher suitability value for attraction. This finding corresponds with the findings of Chernet (2009) and Kebede (2010) according to whom the higher elevation has higher suitability value for scenic attraction because such a land feature is usually not found everywhere, and it is attractive to human vision. For mountain tourism suitability, the highest elevation is preferable.

\subsection{Mountain tourism planning of ASL and environs}

Figure 4 and Table 5 illustrate the pictorial representation and attributes of the locations suitable for mountain tourism activities and development in the study area.

The study revealed that the largest portion of the area (117.05 hectares, 61.40\%), suitable for tourism activities and development is the frontcountry zone. It is followed by the centre zone $(38.50 \%$ of the land cover area, 73.39 hectares) in terms of suitability for tourism activities and development associated with tourism. Lastly, the backcountry zone is the smallest portion of the area under study (0.18 hectares, $0.10 \%)$, suitable for tourism activities and development.

The centre zone is most preferred by tourists, while residents tend to avoid these places for their recreational pursuits, as it is one of the several established resort towns, and because the tourism centre has the lowest mountain ruggedness and the lowest elevation, which would make tourism activities suitable. This study showed that the core tourism activities are cultural, recreational, sports and relaxation, which are the primary motivations of tourists visiting these places (Nepal and Chipeniuk, 2005).

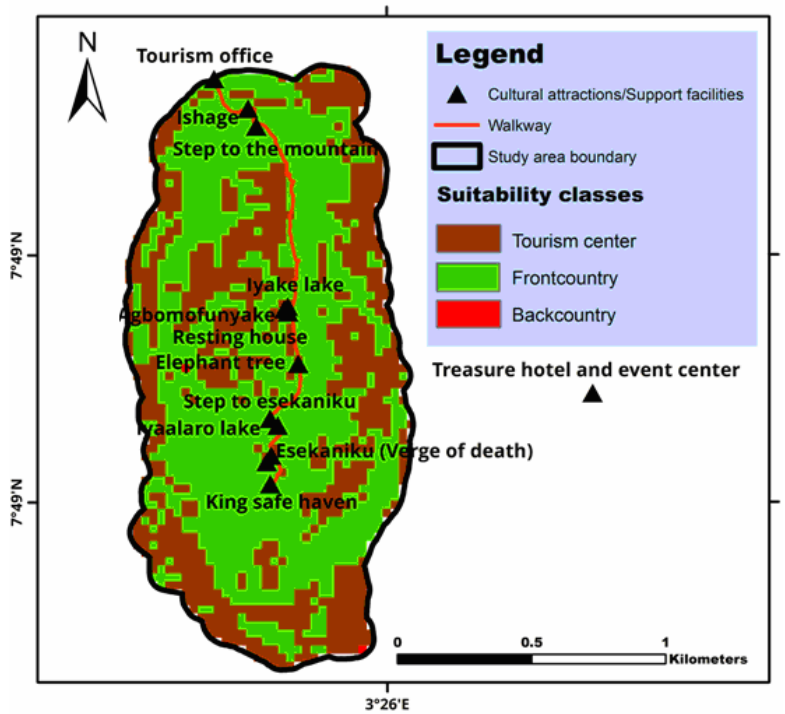

Fig. 4. Location suitability model for mountain tourism activities and development in the area of Ado-Awaye Suspended Lake, Oyo State, Nigeria.

Table 5. Attributes of the locations suitable for mountain tourism activities and development in the area of Ado-Awaye Suspended Lake, Oyo State, Nigeria.

\begin{tabular}{l|rr} 
Suitability classes & Area (ha) & Share (\%) \\
\hline Tourism center & 73.39 & 38.50 \\
Frontcountry & 117.05 & 61.40 \\
Backcountry & 0.18 & 0.10 \\
Total Field survey (2019). & 190.62 & 100.00 \\
\multicolumn{2}{r|}{} \\
\hline \multicolumn{2}{r}{}
\end{tabular}

The duration of visits may range from overnight to several days. In the frontcountry area, activities are less intense but the average time spent for specific activities may be longer. It provides conditions for more nature-orientated activities, ranging from camping and hiking to experiencing native/ethnic culture, wildlife viewing and nature photography. The duration of the visit is shorter. The findings showed that the backcountry activities, namely hiking and trekking, cannot be done at the destination since the elevation does not comply with the standards of backcountry activities.

\section{CONCLUSION}

ASL is blessed with enormous ecotourism attractions but with inadequate and poorly maintained support facilities to enhance the experience and satisfaction of mountain tourists. Currently, the predominant activities that valorise the ecotourism attractions and support facilities are tourism and spiritual activities. This study was able to identify and map tourist attractions and complementary facilities in and around the analysed area. Also, the study 
determined the suitable locations for tourism activities and development coupled with the criteria for determining land suitable for ecotourism in the study area. However, the management of Ado-Awaye should be proactive in working on the dilapidated facilities and further maintaining the ones in good conditions, and also intensive marketing should be done to improve the low intensity of usage and patronage of some ecotourism attractions and support facilities.

Good governance and policy framework from relevant government agencies through collaborative planning for ecotourism development and multistakeholder involvement are highly recommended for the study area. The location suitability model for mountain tourism development should be adopted to develop a new mountain tourism management plan for ASL. This planning process should involve major stakeholders such as the Oyo State Ministry of Information, Culture and Tourism, host communities, non-governmental organizations, international organizations, researchers and private tour-operators. Moreover, management should inculcate wildlife viewing, ski resort, nature photography, camping and recreation to the activities currently performed at the destination.

\section{ACKNOWLEDGEMENTS}

Our sincere gratitude goes to Aro's family for their warm reception and immeasurable assistance in data collection. The useful cooperation of the traditional council members of Ado and Awaye quarters in AdoAwaye town is highly appreciated. Also, we appreciate the intellectual platform provided by the Centre for Diverse Leadership in Science, Institute of the Environment and Sustainability, University of California, the USA through the Early Career Fellowship issued to the first and corresponding author.

\section{REFERENCES}

Anderson J., Hardy E., Roach J., Witmer R. (1976), A land use and land cover classification system for use with remote sensor data. Geological Survey. Washington DC. - References - Scientific Research Publishing. Retrieved from http://www.scirp.org/ reference/ReferencesPapers.aspx?ReferenceID $=135503$ 3

Blasco D., Guia J., Prats L. (2013), Tourism destination zoning in mountain regions: a consumerbased approach, Tourism Geographies: An International Journal of Tourism Space, Place and Environment, DOI:10.1080/14616688.2013.851267

Bunruamkaew K., Murayama Y. (2012), Land use and natural resources planning for sustainable ecotourism using GIS in Surat Thani, Thailand. Sustainability, 4(3), 412-429. DOI: 10.3390/su4030412 Chernet D. (2009), Application of Remote-sensing and GIS for potential ecotourism site selection in Addis Ababa and its surroundings. M.Sc Thesis, pp 34-40.

Chu P., Liu J. K. (2002), Note on Consistency Ratio. Mathematical and Computer Modelling, 35, 1077-1080. DOI: 10.1016/so895-7177(02)00072-9

Dabour N. (2003), Problem and prospects of sustainable tourism development in the OIC countries. Journal of economic cooperation, 39-40.

Ding L., Wang Y., Zhang F., Wu X., Tang S. (2011), Spatial structure of tourist attractions in Nanjing, China: Based on statistical analysis of 317 tourist attractions. Proceedings of the $19^{\text {th }}$ International Conference on Geoinformatics, Shanghai.

Formica S. (2002), Measuring destination attractiveness: A proposed framework. Journal of American Academy of Business, 1(2), 350-355.

Godde P. M., Price M. F., Zimmermann F. M. (2000), Tourism and Development in Mountain Regions. (Wallingford, UK: CABI Publishing).

GOK (2006), National Tourism Policy (Final draft). Nairobi, Kenya.

Gregorio A. D., Henry M., Donegan E., Finegold Y., Latham J ., J onckheere I., Cumani R. (2016), Land cover classification system classification concepts - Software version 3. Rome: Food and Agriculture Organization of the United Nations.

Huddleston B., Ataman E., de Salvo P., Zanetti M., Bloise M., Bel J., Francheschini G., Fe d'Ostiani L. (2003), Towards a GIS-based Analysis of Mountain Environments and Populations. Food and Agriculture Organisation of the United Nations, Rome.

Ibrahim A. T. (2015), Geological Characteristics and Petrographic Analysis of Rocks of Ado-Awaiye and its Environs, Southwestern Nigeria. International Journal of Applied Science and Mathematical Theory, 28-29.

Jeroen K. A. (2017), Tourism Destination Management Insights. Journal Shadow Tales , 6.

Kebede T. (2010), Geospatial approach for ecotourism development: A case of Bale mountains national park, Ethiopia. Addis Ababa University.

Kian B., Zadeh H. H. (2014), An Evaluation of Challenges of Iran Urban Tourism Development Case Study: Tabriz Metropolis. 3rd Interdisciplinary Tourism Research Conference: 71-76.

Kozak M., Bigné E., González A., Andreu L. (2003), Cross-cultural behavior research in tourism: A case study on destination image. Tourism Analysis, 8(2), 253-257. DOI: 10.3727/108354203774077101

Kruk E. A. and Banskota K. (2007), Mountain Tourism in Nepal: From Impacts to Sustainability. In Bisht, H; Rajwar, G (eds) Tourism \& Himalayan Biodiversity. Srinagar:Transmedia Publication. 15-34. 
McCool S., Lachapelle P. R. (2000), Recreational uses of mountain forests, in: Price M. F., Mihai D. (2012), Tourism organization and coordination in Australia. Journal of Knowledge Managerial, Economics and Information Technology, Issue 5, Available at www. Scientificiappars.

Nadube, P. M., Akahome, J . E. (2017), Challenges Facing Customer Patronage of Tourism Destinations in South-South Region of Nigeria. AFRREV, 11(1), 100114. DOI: 10.4314/afrrev.v11i1.8

Nepal S. K., Chipeniuk R. (2005), Mountain Tourism: Toward a Conceptual Framework. Tourism Geographies, 7(3), 313-333. DOI: 10.1080/1461668050 0164849

Olaniyi O. E. (2017), Ecological impacts of ecotourism development and host communities' dependence on Okomu (Nigeria) and Pendjari (Benin Republic) National Parks. Retrieved from https://futa.edu.ng/ projects/frontuser/projectdetails/1605

Olaniyi O. E., Atalor N. O. (2018), Land use/land cover dynamics around ecotourism attractions and support facilities in Ikogosi Warm Spring Resorts (Nigeria). Journal of Forestry Research and Management, 15(1), 197 - 220

Olaniyi O. E., Ogunjemite B. G., Akindele S. O. (2015), Ecotourism Development in Okomu National Park, Nigeria. Journal of Sustainable Development in Africa, 17(7), 51-74.

Panov, N., Taleska, M., Dimeska, H. (2013), The importance of mountain regions for tourism development in Republic of Macedonia. Hilly-Mountain Areas - Problems and Perspectives, Ohrid, 12-15 IX, 547-553

Price M. F., Neville G. R. (2003), Designing strategies to increase the resilience of alpine montane systems to climate change, in: L. J. Hansen, J. L. Biringer and J. R. Hoffman (Eds) Buying Time: A User's Manual for Building Resistance and Resilience to Climate Change in Natural Systems. 73-94 (Gland: WWF).

Racasan, B. S. (2015), Prospecting Event Tourism within the Rural-Mountain Area of Cluj County by Means of Online Promotion. Journal of Settlements and Spatial Planning, Special Issue, no. 4, 199-209

Richins H., J ohnsen S., Hull J . S. (2016), Overview of Mountain Tourism: Substantive Nature, Historical Context, Areas of Focus. In Mountain Tourism: Experiences, Communities, Environments and Sustainable Futures; CABI: Wallingford, UK. 1-12.

Riley S. J., Stephen D. D., Robert E. (1999), A Terrain reggedness index that quantifies topographic hetergeneity . Intermountain Journal of Sciences, 5(24), 23-27.

Saaty T. L. (1980), The analytic hierarchy process. New York, NY: McGraw-Hill.

Siakwah. P. (2018), Tourism Geographies and Spatial Distribution of Tourist Sites in Ghana. African Journal of Hospitality, Tourism and Leisure, 7(1), 1-19

Silva C., Kastenholz E., Abrantes, J. L. (2014), Mountain Destination Image: Towards A Conceptual Framework. 3rd Interdisciplinary Tourism Research Conference, 89-92,

Smethurst D. (2000), Mountain geography. The Geographical Review, 90(1), 35-56. DOI: 10.1111/j.1931-0846.2000.tboo321.x

Stepp J. R. (2000), Mountain ethnobiology and development in highland Chiapas, Mexico: Lessons in biodiversity and health, Mountain Research and Development, 20(3), 218-219. DOI: 10.1659/02764741(2000)020[0218:meadih]2.o.co;2

Tewodros K. (2010), Geospatial approach for Ecoturism Development: a case of Bale Mountain national park. Addis Ababa University.

Thomas C., Gill A., Hartmann R. (2006), Mountain resort planning and development in an era of globalization. New York: Cognizant Communication.

Tourism Queenland (2002), Queensland Ecotourism Plan 2003-2008; Tourism Queensland: Brisbane, Australia, 2002. Online [Available]: http://www.tq.com.au/fms/tq_ corporate/ special interests /ecotourism2/Queensland \%20).

United Nations General Assembly (2016), Sustainable mountain development. Report of the Secretary-General, Seventy-first session Item 19 (j) of the provisional agenda A/71/256. Pp2O

United Nations University (2004), Key issues for mountain areas. Edited by Martin F. Price, Libor F. Jansky, and Andrei A. Iatsenia. United Nations University Press, Tokyo. Pp288

World Tourism Organization (2018), Sustainable Mountain Tourism - Opportunities for Local Communities. UNWTO, Madrid, pp152. DOI: https://doi.org/10.18111/9789284420261

Wu W., Zhang X., Yang Z., Qin W., Wang F., Wang C. (2015), Ecotourism suitability and zoning from the tourist perspective: A nature reserve case study. Polish Journal of Environmental Studies, 24(6), 2683-2697. DOI: 10.15244/pjoes/59422

Zyryanov A. I., Korolev, A. Y. (2009), Touristic zoning of mountain areas. Vestnik Moskovskogo Universiteta, Seriya Geografiya, 6, 19-25. 